\title{
Economic efficiency of Rhipicephalus microplus control and effect on beef cattle performance in the Brazilian Cerrado
}

\author{
Maria Paula Cavuto Abrão Calvano ${ }^{1}$. Ricardo Carneiro Brumatti ${ }^{2}$. \\ Marcos Valério Garcia ${ }^{3,4}$ - Jacqueline Cavalcante Barros ${ }^{5} \cdot$ Renato Andreotti $^{5}$ (D)
}

Received: 1 July 2019 / Accepted: 26 November 2019 / Published online: 30 November 2019

(c) Springer Nature Switzerland AG 2019

\begin{abstract}
The cattle tick Rhipicephalus microplus causes significant economic losses to cattle production systems and is a main barrier to the introduction of Bos taurus breeds and their crosses in Brazil. These breeds have the genetic potential to generate animals that are more productive, but they are also more susceptible to $R$. microplus. One of the alternatives for conventional tick control is the use of strategic control, aiming at delaying or even preventing the development of its resistance to acaricides. The present study aimed to evaluate the economic losses caused by tick infestation on the productive performance of two breeds of beef cattle and to evaluate the economic efficiency of tick strategic control and its impacts on beef cattle production systems. Animal weights were obtained from the literature and were used to calculate the weight loss in kilograms $(\mathrm{kg})$ and the economic loss (US\$) caused by $R$. microplus infestation. The cost/loss ratio of performing strategic control was also calculated. The data show that tick infestation causes economic losses to the breeds and groups of animals evaluated and reduces animal performance (weight loss). The results show a loss of US\$34.61/animal in the backgrounding phase and US\$7.97/animal in the finishing phase for Brangus animals and its crosses. In conclusion, the data show that strategic control is economically efficient for Brangus animals in the backgrounding phase, independent of the methods used for acaricide application.
\end{abstract}

Keywords Bos indicus $\cdot$ Bos taurus $\cdot$ Cost $\cdot$ Economic loss $\cdot$ Infestation $\cdot$ Strategic control

Renato Andreotti

renato.andreotti@embrapa.br

1 Pós-Graduação em Ciência Animal, Faculdade de Medicina Veterinária e Zootecnia, UFMS -

Univ. Federal Mato Grosso do Sul, Campo Grande, Mato Grosso do Sul, Brazil

2 Professor de Pós-Graduação em Ciência Animal, FAMEZ - UFMS, Campo Grande, MS, Brazil

3 Bolsista DCR, Fundect - Governo do Estado de Mato Grosso do Sul, Campo Grande, Mato Grosso do Sul, Brazil

4 Laboratório de Biologia do Carrapato, Embrapa Gado de Corte, Campo Grande, Mato Grosso do Sul, Brazil

5 Embrapa Gado de Corte, Campo Grande, MS, Brazil 


\section{Introduction}

Brazil is one of the main beef-producing and beef-trading countries in the world. This position is reflected in the country's ongoing efforts to increase the productivity and quality of the Brazilian product (Gomes et al. 2017). The cattle production systems used in different farms differ in the quantity and quality of the technologies used (Euclides Filho 2008) and in their environmental, social, and economic conditions (Costa et al. 2018). The systems of commercial beef cattle production are divided into the cow-calf segment and the backgrounding and finishing phases, during which the herd is part of the circulating assets of the rural property (Wedekin 2017).

Central Brazil has favorable environmental conditions for the production of beef cattle (Andreotti et al. 2018), which are better adapted to the environmental conditions of this region (Euclides Filho 2008), as seen, for example, in crosses between Bos taurus and Bos indicus breeds (Menezes et al. 2013). However, a main barrier to the introduction of $B$. taurus and their crosses to the production system is the greater susceptibility of these animals to the cattle tick, Rhipicephalus microplus (Acari: Ixodidae) (Madruga et al. 1985; Andreotti et al. 2018).

The cattle tick is widely distributed in Brazil, and its main host is cattle. This parasite is one of the greatest challenges to the livestock industry in Brazil, because as more crossbred animals are introduced, more changes will occur in the parasitological and economic aspects of extensive farming (Andreotti et al. 2018).

Strategic control aims to reduce the tick population in the host or in pastures, and the use of acaricides, although it is the main line of defense, is just one of the tools in the control process. The efficacy of acaricides is based on the knowledge of the parasite biological cycle, which may result in better control, lower cost, and less impact on the environment by reducing the amount of acaricides as well as slowing the progress of tick resistance to the different products used, including populations of multiresistant ticks (Pereira 2008; Reck et al. 2014; Higa et al. 2015, 2016; Andreotti et al. 2019). Recommendations for strategic control involve a series of five treatments, with an interval of 21 days, at the end of the periods unfavorable for tick development in the pasture (Andreotti et al. 2016a).

Taking the economic losses caused by $R$. microplus into consideration is important when cattle production systems are being analyzed (Andreotti et al. 2016a). Estimates suggest that the total economic loss attributable to $R$. microplus infestations in the Brazilian cattle herd is approximately US\$ 3.2 million per year (Grisi et al. 2014).

The present study aimed to evaluate the economic losses caused by tick infestation on the productive performance of different breeds of beef cattle and to evaluate the economic efficiency of tick strategic control and its impacts on beef cattle production systems.

\section{Materials and methods}

The economic losses caused by $R$. microplus infestations were evaluated for Nellore ( $B$. indicus), Brangus and/or their crosses (B. taurus), possible weight loss (kg) was considered as a function of the average number of ticks. Considering that the weight loss caused by tick infestation is related to the lack of chemical treatment (Andreotti et al. 2016a).

For this study, we examined a herd with 120 and 260 males in the backgrounding and finishing phases, respectively, based on the study of Correa et al. (2006). 


\section{Weight of animals}

For the mean live weight $(\mathrm{kg})$, the data in Table 1 were used.

\section{Cost of infestation}

According to Honer and Gomes (1990), the average weight loss caused by ticks is $0.22 \mathrm{~kg} /$ tick/year. This number was adapted since no specific data are available for cattle in Brazil, and this value was based on a production system with standing cattle and included the effect of parasitic anorexia (Andreotti et al. 2016b). For animals in the backgrounding phase, we considered a weight loss of $0.22 \mathrm{~kg} /$ tick/year because animals stay in this phase for one year. For finishing animals, a three-month finishing period was considered; therefore, the loss was $0.055 \mathrm{~kg} /$ tick/year.

The average number of ticks per animal was based on Andreotti et al. (2018), who evaluated the tick infestation (R. microplus) in Brangus and Nellore animals in Central Brazil in a naturally infested herd, with reference values of 102 ticks/animal/year and 15 ticks/animal/year for Brangus and Nellore, respectively.

The weight loss was estimated using the following formula (Honer and Gomes 1990):

$$
\mathrm{W}=\mathrm{W} \times \mathrm{n}
$$

where $\mathrm{W}$ is the total weight loss $(\mathrm{kg}), \mathrm{w}$ is the weight loss $(\mathrm{kg})$ per tick $(0.22 \mathrm{~kg} / \mathrm{tick} /$ year $)$, and $\mathrm{n}$ is the number of ticks/animal.

$$
\% \text { Loss }=(\text { total weight loss }(\mathrm{kg}) / \text { actual average weight }) \times 100
$$

\section{Cost of treatment}

The cost of treatment was estimated according to the strategic control proposed by Andreotti et al. (2016a); this strategic control includes five acaricide applications every 21 days to reduce tick populations. This strategy can prevent the development of larvae for 105 days, larval populations in the pastures and, consequently, reducing infestations on the animals. That number of treatments and the interval between treatments are recommended for contact acaricides (pour-on and spray). Injectable acaricides last 75 days, and thus, fewer treatments are needed. The product dose followed the manufacturer's recommendation.

Several acaricides are on the market with different active principles, efficacies and methods of application (spray, pour-on, and injectable). The commercial products were chosen according to Higa et al. (2016), who evaluated the resistance of $R$. microplus from several regions of Brazil to different acaricides. The methods of application and the classes of the acaricides used in the analyses were as follows: (a) spraying (organophosphates and pyrethroids), (b) pour-on (organophosphates and pyrethroids), and, (c) injectable (macrocyclic lactones).

The price of the products was quoted in the city of Campo Grande, state of Mato Grosso do Sul, Brazil, and converted to US dollars. The dollar value was estimated as 


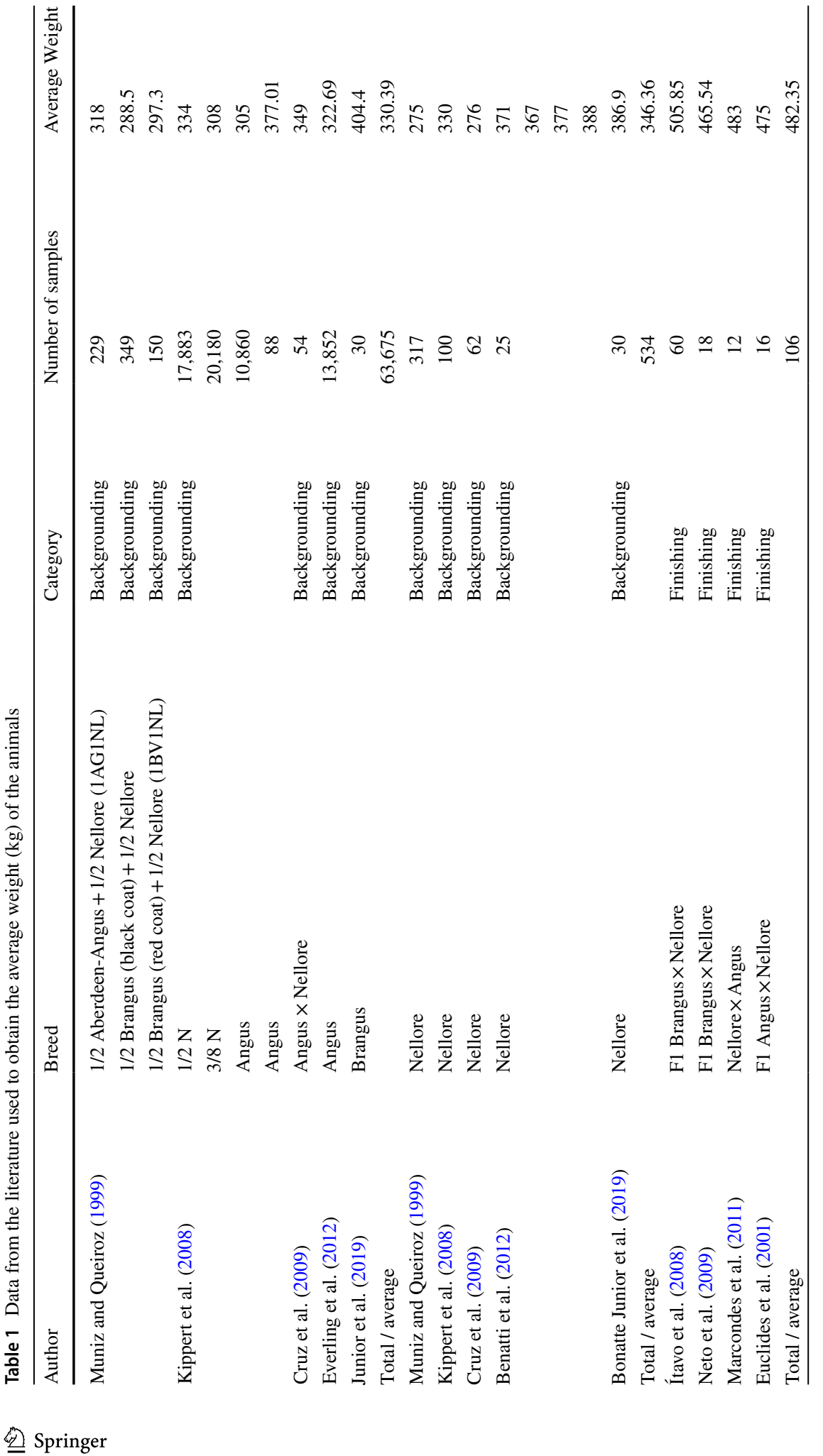




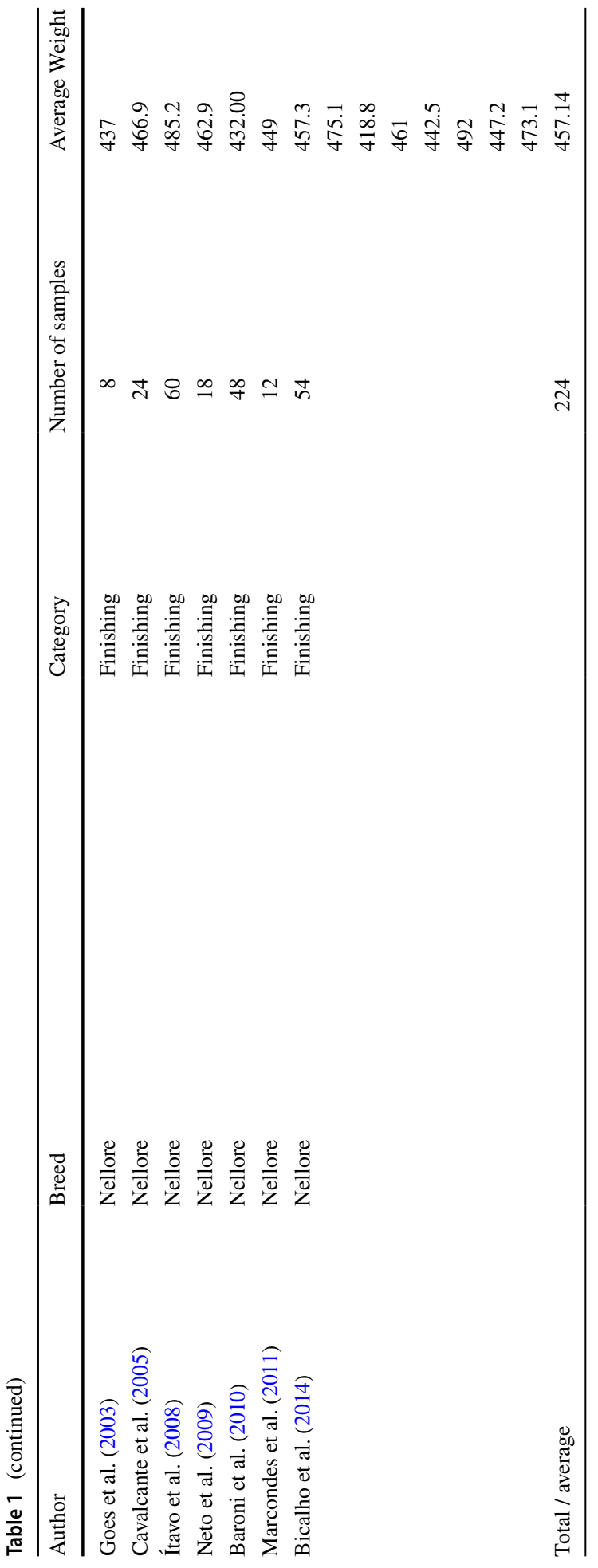


an average of values from 2016 to 2019, and these were obtained from the Center for Advanced Studies in Applied Economics 2019.

The cost of control was estimated using the formula below (Honer and Gomes 1990), which was adapted for the variables available for the calculations:

$$
\mathrm{CT}=\left\{\left(\mathrm{C}_{\mathrm{o}}+\mathrm{C}_{\mathrm{p}}\right) \times \mathrm{N}_{\mathrm{a}}\right\} \times \mathrm{A}
$$

where $\mathrm{CT}$ is the cost of treatment, $\mathrm{C}_{\mathrm{o}}$ is the operational cost, $\mathrm{C}_{\mathrm{p}}$ is the product cost, $\mathrm{N}_{\mathrm{a}}$ is the number of animals per application, and $\mathrm{A}$ is the total number of applications.

The labor force necessary for product application was included in the calculation of the operational costs $\left(\mathrm{C}_{\mathrm{o}}\right)$ :

$$
\mathrm{C}_{\mathrm{L}}=(\mathrm{S} / \mathrm{WH}) / \mathrm{AT}
$$

where $\mathrm{C}_{\mathrm{L}}$ is the cost of labor, $\mathrm{S}$ is the salary, WH is the number of hours worked per day, and AT is the number of animals treated/day.

The number of treatments was 120 and 260 applications/day for animals in the backgrounding and finishing phases, respectively, according to the scenario stipulated for the present study.

To estimate the economic loss, we used the formulas previously described by Mello et al. (2019), adapted according to the information available for the present study.

$$
\begin{gathered}
\mathrm{VA}=(\text { weight estimate } \times \text { yield estimate }) \times \mathrm{US} \$ / \mathrm{kg} \\
\mathrm{VAI}=(\text { weight estimate } \times \text { yield estimate }) \times \mathrm{US} \$ / \mathrm{kg} \text { PV } \\
\mathrm{L}_{\mathrm{Ec}}=\mathrm{VA}-\mathrm{VAI} \\
\mathrm{ImL}=\left(\mathrm{CT} / \mathrm{L}_{\mathrm{Es}}\right) \times 100
\end{gathered}
$$

where VA is the value of an uninfested animal, VAI is the value of an infested animal, PV is live weight, weight estimate is the average weight in $\mathrm{kg}$, yield estimate is the $50 \%$ carcass yield, US\$ is the price paid per kg of live weight, $\mathrm{L}_{\mathrm{Ec}}$ is the economic loss, ImL is the impact of treatment costs on economic loss, and $\mathrm{L}_{\mathrm{Es}}$ is the estimated loss.

\section{Results}

The average weights of the animals were 482.35 and $330.39 \mathrm{~kg}$ for the Brangus, and 457.14 and $346.36 \mathrm{~kg}$ for the Nellore in the finishing and backgrounding categories, respectively.

\section{Economic loss relative to weight $(\mathbf{k g})$}

The total weight loss $(\mathrm{kg})$ is shown in Fig. 1. Brangus animals had the largest weight loss, regardless of the category, with 1.2\% live weight loss for finishing and $6.8 \%$ loss for backgrounding animals. On the other hand, Nellore animals had a live weight loss of $0.2 \%$ and $1.0 \%$ for the finishing and backgrounding phases, respectively. 


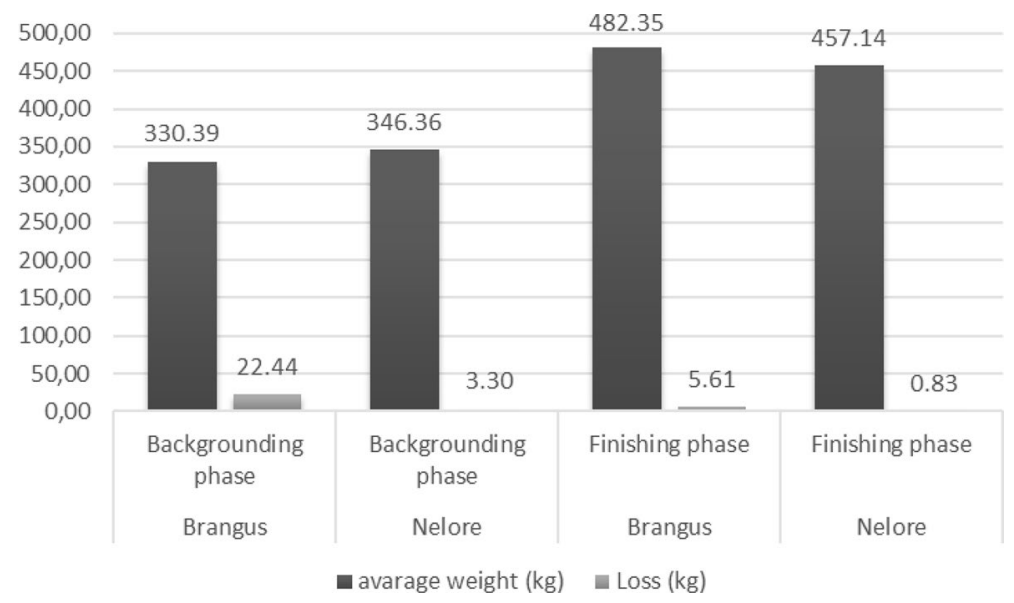

Fig. 1 Estimated weight loss (kg) of animals infested with Rhipicephalus microplus

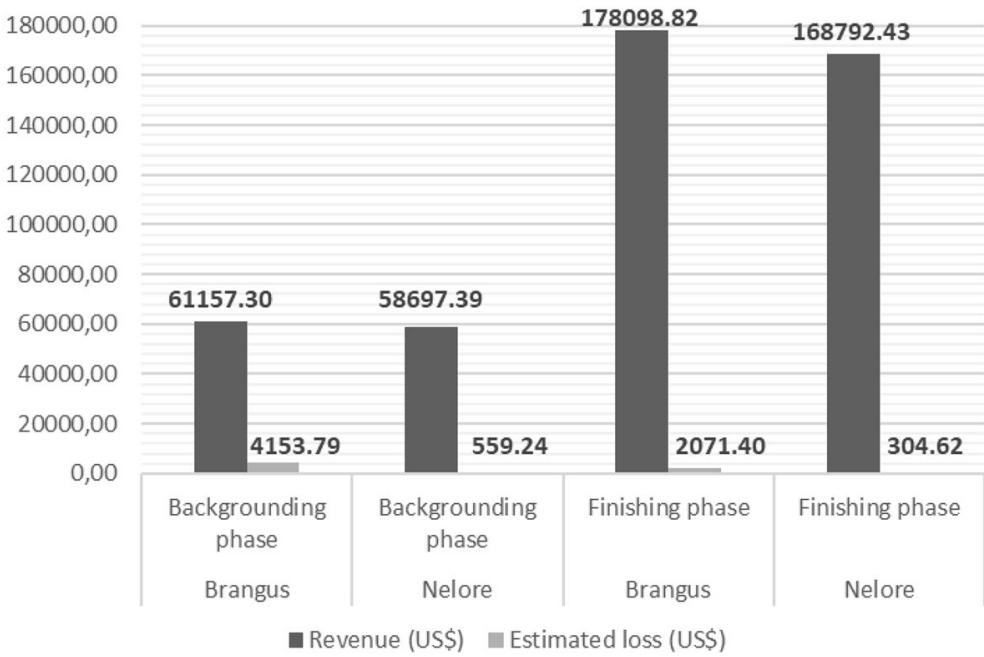

Fig. 2 Comparison of estimated revenue (US\$) and economic loss (US\$) in animals infested with Rhipicephalus microplus for a herd with 120 backgrounding animals and a herd of 260 finishing animals

Figure 2 shows the economic losses caused by tick infestations for each breed and animal phases. Tick infestations caused greater economic loss to Brangus animals than to Nellore animals, and the animals in the finishing phase had an economic loss of US\$ 2071.40, whereas the animals in the backgrounding category had an economic loss of US\$ 4153.79. Tick infestations caused lower economic loss to Nellore than to Brangus animals, regardless of the phase. 


\section{Cost of infestation}

The amount paid for animals in the finishing phase was US $\$ 2.84 / \mathrm{kg}$ regardless of the breed. For animals in the backgrounding phase, the price was US $\$ 1.41 / \mathrm{kg}$ for Nellore and US\$1.54/kg for Brangus.

The estimated value of a Brangus animal in the finishing category was US\$ 685.00/animal, with a loss of US\$7.97/animal due to tick infestation. For animals in the backgrounding phase, the estimated value was US\$ 509.64/animal, with a loss of US\$ 34.61/animal. Nellore animals had an estimated value of US\$649.20/animal, with a loss of US\$1.18/animal, and US\$ 489.11, with a loss of US\$ 4.66/animal, for the finishing and backgrounding phases, respectively.

\section{Cost of treatment}

The cost of treatment was estimated for the three methods of application separately. For spraying, the cost of treatment was US\$2.25/animal, regardless of breed and phase because the volume of acaricide applied per animal is not affected by the animal's weight. Taking into account the 260 finishing animals and one application in a three-month period, the cost of treatment was US\$107.89. For the 120 animals in the backgrounding phase and five applications in a year, the total cost of treatment was US\$269.60.

For Brangus animals, the cost of treatment relative to the economic loss was $5.6 \%$ and $6.5 \%$ for animals in the finishing and backgrounding phases, respectively, whereas for Nellore animals, the cost of treatment relative to the economic loss was $38.4 \%$ and $48.2 \%$ for animals in the finishing and backgrounding phases, respectively (Fig. 3).

The cost of pour-on control for animals in the finishing and backgrounding phases was US\$0.55/animal and US\$1.85/animal, respectively. The relationship between the cost of pour-on treatment and economic losses was $6.5 \%$ for Brangus animals, $39.7 \%$ for Nellore animals in the backgrounding phase, and $145.1 \%$ for Nellore animals in the finishing phase (Fig. 4).

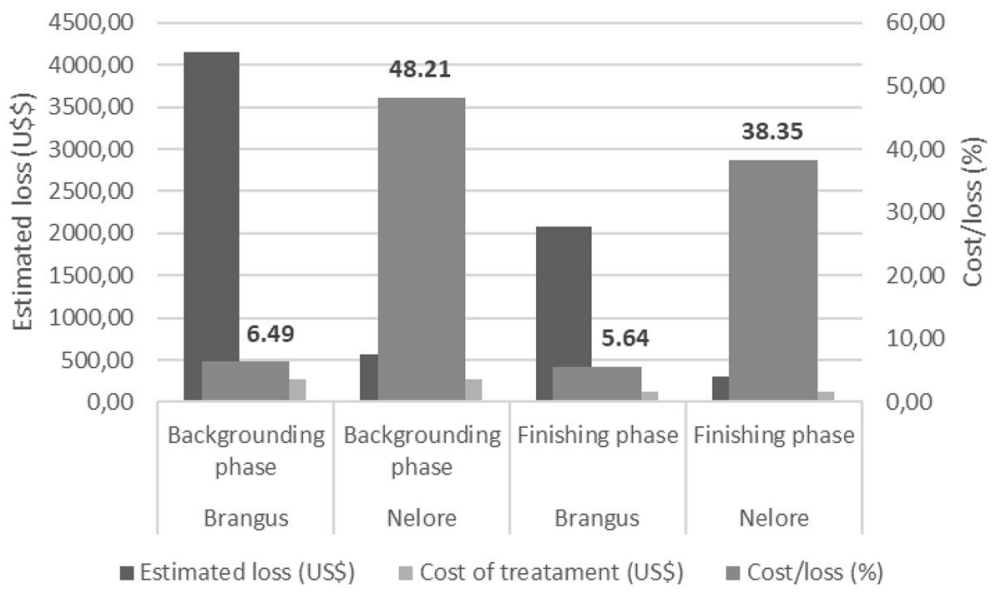

Fig. 3 Relationship between spraying costs and economic losses due to Rhipicephalus microplus infestation 


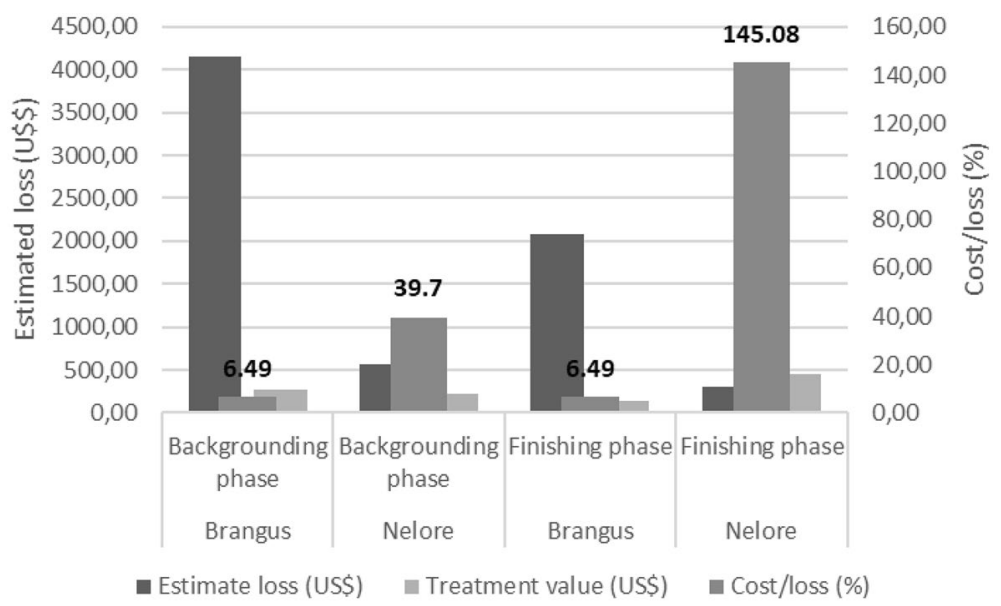

Fig. 4 Relationship between the cost of pour-on treatment and economic losses due to Rhipicephalus microplus infestation

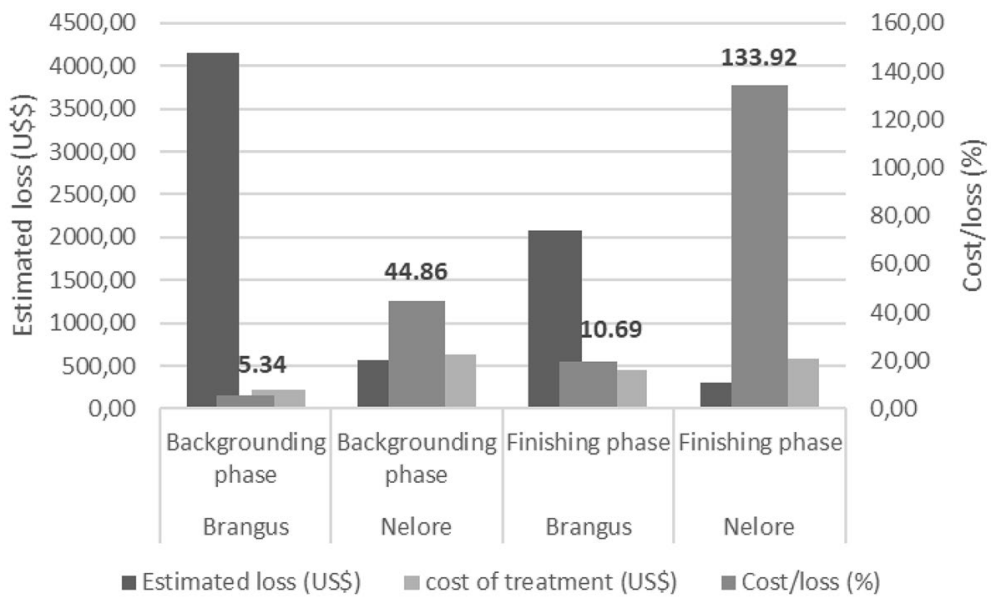

Fig. 5 Relationship between the cost of injectable treatments and economic losses due to Rhipicephalus microplus infestation

The costs of the injectable treatment for animals in the backgrounding and finishing phases were US\$2.09/animal and US\$1.70/animal, respectively. The lowest cost/loss ratio was observed for Brangus animals in the backgrounding phase, and the largest, for Nellore animals (Fig. 5).

The figures above show the economic efficiency for all treatments for Brangus animals regardless of the category. 


\section{Discussion}

The results of the present study demonstrate that Nellore and Brangus animals and their crossbreeds lose weight when infested with $R$. microplus. The highest weight losses were observed in Brangus animals, mainly in the backgrounding phase, during which they lost $6.89 \%$ of their live weights. By extrapolating the data to a herd with more animals, the losses become more evident. For example, for 1000 animals in the backgrounding phase, the loss would total $22,440 \mathrm{~kg} / \mathrm{year}$, and for the same number of animals in the finishing phase, the total loss would be $5610 \mathrm{~kg}$ in three months. These data demonstrate a negative effect on the animals' meat production performance. Crosses between European (adapted or not) and zebu breeds generally result in animals with good reproductive capacity in tropical environments, and these animals are better at gaining weight (Filho 2008; Euclides et al. 2014).

The results of the present study demonstrate that tick infestations cause economic losses; thus, producers have lower profits, and these profits could be used for the purchase of replacement animals, which comprise the most expensive item of the backgrounding-finishing system, followed by the expenditures for minerals and concentrates (Wedekin 2017). Animals in the finishing phase had the highest revenues estimated in US\$ 346,891.20, and the economic loss caused by tick infestation in this same category was US\$2376.00. For animals in the backgrounding phase, the revenue was US\$118,956.20, which is lower than that found for the finishing phase, and the loss for animals in the backgrounding phase was higher, totaling US\$ 4713.03. We evaluated the backgrounding and finishing phases because they represent two important stages in beef cattle production systems. The backgrounding phase is when the animal develops muscle mass and bone structure, and finishing is when the animal gains weight by faster deposition of muscle and fat. At slaughter, the most important aspect of body composition is the proportion of muscle and fat in the carcass because it determines most of the animal's economic value and affects the efficiency and costs of meat production (Berg and Butterfield 1979).

Nellore animals compose most of the beef cattle herd of Central Brazil because they are more adaptable to tropical conditions (Wedekin 2017). In our study, Nellore animals had little economic and weight loss due to tick infestation because this breed is more resistant to ticks. According to Veríssimo (1999), animals with 25 or fewer ticks on one side, which would result in low or almost no economic loss, are resistant to ticks.

Strategic control aims to reduce the tick population on animals through lower applications of acaricides (Andreotti et al. 2019). The analyses of the strategic control costs demonstrate that strategic control is economically viable for Brangus animals in the backgrounding phase, regardless of the method of application. Thus, the strategic control contributes to the development of the Brangus' genetic potential and to a more efficient production system. Bonatte Junior et al. (2019) reported that high tick counts in Brangus animals coincide with the postweaning period, when the animals are highly stressed, which may affect their immunological resistance and favor parasitism. Brangus animals that received no treatment had the lowest weight gain, greater number of ticks and higher expenses for bovine babesiosis and anaplasmosis prophylactic treatments and myiasis curative treatments (Bonatte Júnior et al. 2019).

For the other categories, the relationship between the cost of treatment and economic losses due to $R$. microplus infestation varies according to the method of application. In Nellore animals, control is not necessarily economically efficient; thus, for Nellore animals, the use of acaricides should be analyzed case by case. According to Andreotti et al. 
(2018), in a situation where tick infestation has little effect on pure $B$. indicus animals such as Nellore, acaricides should not be used; however, when B. taurus and Bos indicus animals are raised in the same environment, the tick population tends to increase, thereby requiring the use of acaricides.

In 2018, Brazil produced 10.96 million carcass weight equivalents, which was an increase of $12.8 \%$ over 2017. The state of Mato Grosso do Sul has a cattle herd of 21,670,275 head with beef genetic traits (Abiec 2019). Therefore, the potential exists for beef production, and strategic control can help reduce tick infestations and, consequently, increase productivity.

The hypothetical analysis performed in this study, which analyzed, in terms of the technical and financial performance of beef production, the economic losses caused by tick infestation by considering weight loss in kilograms (Honer and Gomes 1990), while also updating data on the number of ticks (Andreotti et al. 2018), corroborated other studies that showed the tick $R$. microplus causes economic losses to the beef cattle production system (Gomes 1990; Grisi et al. 2014; Andreotti et al. 2018). The data suggest that it is important to compare the productivity loss to the economic efficiency of the strategic control because, when the cost of control is compared to the economic losses caused by tick infestations (cost/loss), the control may be economically efficient for reducing tick infestations.

Acknowledgements The authors thank the Coordination for the Improvement of Higher Education Personnel (Coordenação de Aperfeiçoamento de Pessoal de Nível Superior-Capes), National Council for Scientific and Technological Development (Conselho Nacional de Desenvolvimento Científico e Tecnológico - CNPq), and the Mato Grosso do Sul State Foundation for the Support and Development of Education (Fundação de Apoio ao Desenvolvimento do Ensino, Ciência e Tecnologia do Estado de Mato Grosso do Sul - Fundect, MS) - Governo do Estado de Mato Grosso do Sul.

Author contributions MPCAC, RCB and RA: designed the study, analyzed the data and wrote the manuscript; MVG and JCB: analyzed the data.

\section{Compliance with ethical standards}

Conflict of interest There were no conflicts of interest that may have biased the work reported in this paper.

\section{References}

Abiec (2019) O perfil da pecuária no Brasil. http://www.abiec.com.br/controle/uploads/arquivos/sumar io2019portugues.pdf. Accessed 10 Apr 2019

Andreotti R, Garcia M, Koller W (2016a) Carrapatos: protocolos e técnicas para estudo. Embrapa 240 ISBN: 978-85-7035-550-8

Andreotti R, Garcia M, Reis F, Rodrigues V, Barros J (2016b) Proposta de controle de carrapato para o Brasil Central em sistemas de produção de bovinos associados ao manejo nutricional no campo. Embrapa DF Documento 214 ISSN 1983-974-X

Andreotti R, Barros J, Garcia M, Rodrigues V, Higa L, Duarte P, Blecha I, Bonatte-Junior P (2018) Cattle tick infestation in Brangus cattle raised with Nellore in central Brazil. Semina Ciênc Agrár 39:1099. https://doi.org/10.5433/1679-0359.2018v39n3p1099

Andreotti R, Garcia M, Koller W (2019) Carrapatos na cadeia produtiva de bovinos. In: Controle estratégico dos carrapatos nos bovinos. Embrapa, p 125 ISBN 978-85-7035-230-9

Baroni CES, Lana RP, Mancio AB, Queiroz AC, Sverzut CB, Mendonça BPC (2010) Desempenho de novilhos suplementados e terminados em pasto, na seca, e avaliação do pasto. Arq Bras Med Vet Zootec 62:373-381. https://doi.org/10.1590/S0102-09352010000200018

Benatti JMB, Moraes EHBKD, Zervoudakis JT, Araújo CVD, Cabral LDS, Rufino Junior J, Carvalho DMGd (2012) Fornecimento de grão de milheto, inteiro ou triturado, em duas frequências de 
suplementação para bovinos de corte. Rev Bras Zootec 41:941-950. https://doi.org/10.1590/S1516 $-35982012000400016$

Berg R, Butterfield R (1979) Nuevos conceptos sobre desarrollo de ganado vacuno. Acribia, Zaragoza

Bicalho FL, Barbosa FA, Graça DS, Filho SLSC, Leão JM, Lobo CF (2014) Desempenho e análise econômica de novilhos Nelore submetidos a diferentes estratégias de suplementação alimentar nas fases de recria e engorda. Arq Bras Med Vet Zootec 66:1112-1120. https://doi.org/10.1590/1678-6369

Cavalcante MAB, Pereira OG, Filho SDCV, Ribeiro KG (2005) Níveis de proteína bruta em dietas para bovinos de corte: consumo, digestibilidade total e desempenho produtivo. Rev Bras Zootec 34:711719. https://doi.org/10.1590/S1516-35982005000300001

Centro de Estudos Avançados em Economia Aplicada-ESALQ/USP Preço do boi gordo. http://www.cepea .esalq.usp.br. Accessed 29 Jan 2019

Correa E, Costa F, Filho G, Pereira M (2006) Sistema de produção melhorados para gado de corte em Mato Grosso do Sul. Embrapa Comunicado Técnico 102. ISSN: 1516-9308

Costa F, Dias F, Gomes R, Pereira M (2018) Indicadores de desempenho na pecuária de corte: uma revisão no contexto da Plataforma +Precoce. Embrapa Comunicado Técnico 93: 8 ISSN 1517-3747

Cruz GMD, Rodrigues ADA, Tullio RR, Alencar MMD, Alleoni GF, Oliveira GPD (2009) Desempenho de bezerros da raça Nelore e cruzados desmamados recebendo concentrado em pastagem adubada de Cynodon dactylon cv. Coastcross. Rev Bras Zootec 38:139-148. https://doi.org/10.1590/S1516-35982 009000100018

Euclides VPB, Euclides Filho K, Costa FP, Figueiredo GRD (2001) Desempenho de novilhos F1 s AngusNelore em pastagens de Brachiaria decumbens submetidos a diferentes regimes alimentares. Rev Bras Zootec 30:470-481. https://doi.org/10.1590/S1516-35982001000200025

Euclides VPB, Filho KE, Montagner DB, Figueiredo GR, Lopes FDC (2014) Alternatives for intensification of beef production under grazing. Trop Grassl Forrajes Trop 2:48-50. https://doi.org/10.17138/ TGFT(2)48-50

Everling DM, Rorato PRN, Araujo ROD, Boligon AA, Bresolin T, Dornelles MA, Weber T, Pacheco PS, Campos LT (2012) Associação genética de escores de conformação com características de crescimento em bovinos da raça Angus. Pesqui Agropecu Bras 47:1524-1532. https://doi.org/10.1590/S0100 $-204 X 2012001000016$

Filho KE (2008) A pecuária de corte no Cerrado Brasileiro. In: Faleiro F, Neto A (eds) Savanas: desafios e estratégia para o equilíbrio entre sociedade, agronegócio e recursos naturais. Embrapa Cerrados, Planaltina, pp 613-644

Goes RHDTBD, Mancio AB, Lana RDP, Filho SDCV, Cecon PR, Queiroz ACD, Lopes AM (2003) Desempenho de novilhos Nelore em pastejo na época das águas: ganho de peso, consumo e parâmetros ruminais. Rev Bras Zootec 32:214-221. https://doi.org/10.1590/S1516-35982003000100027

Gomes A (1990) Controle do carrapato-do-boi: um problema para quem cria raças europeias. Embrapa Boletim Técnico 31

Gomes R, Feijó G, Chiari L (2017) Evolução e qualidade da pecuária Brasileira. Embrapa Gado de Corte, Campo Grande

Grisi L, Leite RC, Martins JR, Barros AT, Andreotti R, Cancado PH, Leon AA, Pereira JB, Villela HS (2014) Reassessment of the potential economic impact of cattle parasites in Brazil. Rev Bras Parasitol Vet 23:150-156. https://doi.org/10.1590/S1984-29612014042

Higa L, Garcia M, Barros J, Koller W, Andreotti R (2015) Acaricide resistance status of the Rhipicephalus microplus in Brazil: a literature overview. Med Chem 5:326. https://doi.org/10.4172/2161-0444.10002 81

Higa LDOS, Garcia MV, Barros JC, Koller WW, Andreotti R (2016) Evaluation of Rhipicephalus (Boophilus) microplus (Acari: Ixodidae) resistance to different acaricide formulations using samples from Brazilian properties. Rev Bras Parasitol Vet 25:163-171. https://doi.org/10.1590/S1984-29612016026

Honer M, Gomes A (1990) O manejo integrado de mosca dos chifres, berne e carrapato em gado de corte. EMBRAPA-CNPGC, Campo Grande

Ítavo LCV, Tolentino TCP, Ítavo CCBF, Gomes RC, Dias AM, Silva FF (2008) Consumo, desempenho e parâmetros econômicos de novilhos Nelore e F1 Brangus x Nelore terminados em pastagens, suplementados com mistura mineral e sal nitrogenado com uréia ou amiréia. Arq Bras Med Vet Zootec 60:419-427. https://doi.org/10.1590/S0102-09352008000200022

Junior PB, Rodrigues VDS, Garcia MV, Higa LOS, Zimmermann NP, Barros JC, Andreotti R (2019) Economic performance evaluation of Brangus and Nellore cattle breed naturally infested with Rhipicephalus microplus in an extensive production system in Central-West Brazil. Exp Appl Acarol 78:565-577. https://doi.org/10.1007/s10493-019-00404-1

Kippert CJ, Rorato PRN, Lopes JS, Weber T, Boligon AA (2008) Efeitos genéticos aditivos diretos e maternos e heterozigóticos sobre os desempenhos pré e pós-desmama em uma população multirracial 
Aberdeen Angus $\times$ Nelore. Rev Bras Zootec 37:1383-1391. https://doi.org/10.1590/S1516-35982 008000800007

Madruga C, Kessler R, Gomes A, Schenck M, Andrade D (1985) Níveis de anticorpos e parasitemia de anaplasma marginale em área enzoótica nos bezerros da raça Nelore, Ibagé e cruzamentos Nelore. Pesq Agrop Bras 20:135-142

Marcondes MI, Valadares Filho SDC, Oliveira IMD, Paulino PVR, Valadares RFD, Detmann E (2011) Eficiência alimentar de bovinos puros e mestiços recebendo alto ou baixo nível de concentrado. Rev Bras Zootec 40:1313-1324. https://doi.org/10.1590/S1516-35982011000600021

Mello AKM, Brumatti RC, Neves DA, Alcântara LOB, Araújo FS, Gaspar AO, Lemos RAA (2019) Bovine rabies: economic loss and its mitigation through antirabies vaccination. Pesq Vet Bras 39:179-185. https://doi.org/10.1590/1678-5150-pvb-6201

Menezes LMD, Pedrosa AC, Pedroso D, Fernandes S (2013) Desempenho de bovinos Nelore e cruzados Blonde d'Aquitaine x Nelore do nascimento ao desmame. Rev Bras Saúde Prod Anim 14:177-184. https://doi.org/10.1590/S1519-99402013000100018

Muniz CADSD, Queiroz SAD (1999) Avaliação de características de crescimento pós-desmama de animais Nelore puros e cruzados no estado do Mato Grosso do Sul. Rev Bras Zootec 28:713-720. https://doi. org/10.1590/S1516-35981999000400009

Neto AP, Jorge AM, Moreira PSA, Gomes HFB, Pinheiro RSB (2009) Desempenho e qualidade da carne de bovinos Nelore e F1 Brangus x Nelore recebendo suplemento com cromo complexado à molécula orgânica na terminação a pasto. Rev Bras Zootec 38:737-745. https://doi.org/10.1590/S1516-35982 009000400021

Pereira A (2008) Aspectos da ecologia de Boophilus microplus (CANESTRINI, 1887) (ACARINA: IXODIDAE) no município de Franca, nordeste de São Paulo. Tese (doutorado), Universidade Estadual Paulista, Faculdade de Ciências Agrárias e Veterinárias

Reck J, Klafke GM, Webster A, Dall'Agnol B, Scheffer R, Souza UA, Corassini VB, Vargas R, Dos Santos JS, Martins JR (2014) First report of fluazuron resistance in Rhipicephalus microplus: a field tick population resistant to six classes of acaricides. Vet Parasitol 201:128-136. https://doi.org/10.1016/j. vetpar.2014.01.012

Veríssimo C (1999) Controle biológico do carrapato. In: Simpósio de agricultura ecológica. Agropecuária, Guaíba Anais... Guaíba, Editora Agropecuária, pp 205-215

Wedekin I (2017) Economia da pecuária de corte: fundamentos e ciclos de preços. Wedekin Consultores, São Paulo

Publisher's Note Springer Nature remains neutral with regard to jurisdictional claims in published maps and institutional affiliations. 